\title{
Питання психології
}

DOI: $10.33099 / 2617-6858-2019-52-2-87-94$

Павлушенко С. слухач Інституту державного воєнного управління Національного університету оборони

України імені Івана Черняховського

\section{ПСИХОЛОГІЧНІ НАСЛІДКИ УЧАСТІ ОСОБИСТОСТІ В БОЙОВИХ ДІЯХ}

У статті розглянуто стрес-фактори бойової обстановки; проаналізовано етапи, механізми $і$ соціально-психологічні детермінанти, які визначають прочес переживання військовослужбовцем психічної травми.

Ключові слова: психологічна допомога; психологічна реабілітація; посттравматичні стресові розлади.

Постановка проблеми. Тривалий військовий конфлікт на території Донецької та Луганської областей держави, його подальша невизначеність, потенційна загроза життю та здоров'ю, тривале перебування в районі проведення бойових дій, невлаштованість побуту, великі фізичні та психологічні навантаження на особовий склад та інші фактори бойової обстановки спричиняють короткі і тривалі розлади психіки, знижують боєздатність військових частин (підрозділів). За оцінками ряду експертів та науковців психогенні втрати в сучасних війнах можуть складати до $30 \%$ i значно перевищують кількість санітарних втрат. Аналізуючи війни на Близькому Сході 1973 і 1982 років, спеціалісти визначили, що відношення психічних втрат до кількості поранених відповідно становило 26:100 i 23:100.

Згідно досліджень Ю. Дедова, Л. Ярцева, середній відсоток психічних втрат особового складу залежить від рівня функціонування військ: під час мирної діяльності - 4-6\%, у навчально-бойовій діяльності - 15-20\%, у бою - 30-86\% (значна розбіжність даних залежить від факторів бою та їх впливу на психіку особового складу) $[9,77]$.

Практика показує, що знання психотравмуючих факторів сучасного бою та їх наслідків дозволяє психологічно до них підготуватися.

Ознайомлення військовослужбовців із типами можливих реакцій на бойові стрес-фактори $\epsilon$ своєрідним "щепленням", що діє за принципом "попереджений - захищений". На цей факт ще на початку XX ст. вказував відомий військовий психолог Г. Є. Шумков, який вважав, що “завчасне ознайомлення особового складу з умовами бою $є$ завчасним накопиченням бойового досвіду". Разом 3 набуттям бойового досвіду, учасники війни на Сході нашої держави зазнають фізичних та психологічних травм, потребуючи в подальшому фахової допомоги та реабілітації. Створення дієвої системи психологічної допомоги та реабілітації в умовах сьогодення можливо лише за умови розуміння психологічних наслідків участі особового складу у бойових діях на території Донецької та Луганської областей.

Аналіз останніх досліджень i публікацій. Проблема негативних наслідків для психіки військовослужбовців стала предметом значної кількості наукових досліджень як вітчизняних, так i зарубіжних вчених: Н. Агаєва, В. Березовця, А. Бравее, В. Знакова, В. Ковтуна, М. Корольчука, В. Крайнюка, 3. Комара, А. Маклакова, В. Попова, В. Стасюка, Д. Шпігеля та інших. Більшість авторів вказують на те, що детермінантами негативних наслідків виступають різноманітні стрес-фактори, які $\epsilon$ невід'ємною складовою бойової обстановки. Разом з тим, мало висвітленим залишається питання аналізу психологічних наслідків участі комбатантів в бойових діях.

Метою статті $\epsilon$ аналіз психологічних наслідків участі військовослужбовців в бойових діях.

Методи дослідження. Для вирішення поставлених у роботі завдань були використані теоретичні методи дослідження: аналіз наукових джерел 3 проблеми дослідження, синтез, порівняння, узагальнення.

Виклад основного матеріалу. Для того, щоб вижити в умовах стрес-факторів бойової обстановки та виконати поставлені бойові завдання учасники бойових дій повинні 


\section{Питання психології}

перебудувати всі рівні свого існування (психофізіологічний, психологічний, соціальний) у відповідності до вимог цієї обстановки. Таке пристосування до бойової обстановки залежить від психологічного потенціалу військовослужбовця. Цікаві дослідження залежності бойової адаптації і динаміки психологічних можливостей військовослужбовця від часу перебування їх на передовій в умовах безпосереднього контакту 3 противником провели П.С. Дінтер і Р.А. Габрієль. Так П.С. Дінтер виявив наступну закономірність: процес адаптації до бойових дій триває 15-25 діб; протягом цього терміну військовослужбовець досягає піку моральнопсихологічних можливостей; після 30-40 діб безупинного перебування в безпосередньому зіткненні із противником настає їх швидкий спад, пов'язаний із виснаженням духовних і фізичних сил. Вчений наголошуе, що перебування воїнів в умовах безпосереднього зіткнення 3 противником повинно не перевищувати 40 діб.

$$
\text { Процес }
$$

військовослужбовців до бойової обстановки Р.А. Габрієль описує як поетапне наростання у них бойової втоми і втрату боєздатності. Після завершення детального дослідження Р.А. Габрієль дійшов висновку: якщо після 45 діб безупинного перебування на полі бою військовослужбовців не відправити в тил, вони за своїми психофізіологічними можливостями виявляться небоєздатними. Аналогічної точки зору дотримуються американські психіатри Р. Свояк та У. Маршан, на думку яких у 98\% військовослужбовців, що безперервно беруть участь у бойових діях протягом 35 діб, виникають психічні розлади $[9,100-$ 102].

Загалом, кожна людина володіє певним адаптаційним потенціалом або психологічним ресурсом, який дозволяє долати стрес-фактори певної інтенсивності, проте, якщо сила або тривалість несприятливих зовнішніх впливів перевищує індивідуальні пристосувальні можливості, відбувається психічне травмування людини.

У наукових джерелах бойова психічна травма розглядається як патологічний стан центральної нервової системи, що виникає внаслідок впливу бойових стрес-факторів i спричиняє наростання специфічної особистісної дисгармонії i готовності до психопатологічного синдромоутворення. У більшості випадків психіка будь-якої людини прагне до самовідновлення після травмування, проте далеко не завжди людина може віднайти відповідні ресурси (психічні, матеріальні, зовнішні, внутрішні), самостійно розробити ефективну стратегію та набути відповідних практичних навичок у подоланні наслідків травматизації. Особливо дане ствердження стосується надсильних потрясінь (так звані “Т”- травми), пов'язаних із загибеллю людей, втратою накопичених за життя матеріальних цінностей, втратою звичного місця проживання тощо [2, 3]. У таких випадках необхідна спеціально розроблена, законодавчо обгрунтована й організована на усіх рівнях військового управління система психологічної допомоги та реабілітації постраждалих внаслідок проведення операції Об'єднаних сил на Сході України.

3 метою вірної постановки цілей та завдань психологічної допомоги та реабілітації, добору адекватних методів надання психологічної допомоги травмованим особам, залучення відповідного ресурсу (фахівці, необхідне обладнання, фінансування тощо) необхідно мати чітке уявлення про етапи, механізми i соціально-психологічні детермінанти, які визначають процес переживання людиною психічної травми.

Так, більшість сучасних дослідників в динаміці станів та реакцій людини (без важких поранень та пошкоджень) виділяють 7 послідовних стадій пристосування до дій стрес-факторів бойової обстановки при короткочасному перебуванні в осередку екстремальної ситуації:

стадія вітальних реакцій заціпеніння (триває ця стадія від декількох секунд до 5-15 хвилин);

стадія гострого психоемоційного шоку 3 явищами “зверхмобілізаціі” напруження

( триває близько 3-5 годин);

$$
\text { стадія психофізіологічної }
$$

демобілізації - "стрес усвідомлення" (триває до трьох діб);

стадія вирішення - стабілізації

(триває від 3 до 12 діб); 


\section{Питання психології}

стадія

відновлення

психофізіологічного стану (розпочинається 3 другого тижня і триває до місяця після психотравмування людини);

стадія відстрочених реакцій - стійкі порушення сну, немотивовані страхи, кошмарні сновидіння, нав'язливість та бредово-галюцинаторні стани (починається через місяць після виникнення екстремальної ситуації);

стація віддалених наслідків - стійка психопатологія пережитих реакцій (триває від 6-7 місяців до декількох десятків років) $[3,36-42 ; 9,45 ; 11,55]$.

При травмуванні людей під час короткочасного перебування в осередку екстремальної ситуації найкраще підійдуть стратегія, принципи й методи екстреної психологічної допомоги, короткострокової психотерапії та психопрофілактики. Метою даних методів психологічної допомоги $\epsilon$ запобігання виникненню та розвитку віддалених негативних наслідків психотравмування та надання підтримки, перш за все, з метою підвищення опірності та здатності людини протистояти екстремальному впливу.

Вивчення процесу розвитку психічної травми внаслідок тривалого перебування в умовах екстремальної ситуації (бойових дій) змушує нас говорити, як мінімум, про три періоди:

1. Початковий період або період потрапляння в тривалу психотравмуючу ситуацію. Це період так званих первинних реакцій, який відповідає періоду переживання короткострокової травмуючої події. Власне цей період первинних реакцій і є переживанням короткострокової, поки що, травми. Відповідно, ми можемо виділити все ті ж стадії в процесі переживання цього періоду травми, що i при короткочасному перебуванні людини в умовах екстремальної ситуації.

2. Період перебування у тривалій психотравмуючій ситуації або період адаптації. Характерні для цієї стадії прояви значною мірою визначаються тим, до яких саме умов адаптується військовослужбовець. На думку більшості дослідників, для реакцій військовослужбовців на даному етапі характерні дві основні ознаки: апатія та агресія. Крім того, не можна забувати, що в цей час відбувається адаптація до екстремальних стрес-факторів бойової обстановки, які викликають підвищену напругу всіх функцій організму людини. Отже, надто тривале перебування в екстремальних умовах практично завжди призводить до виснаження всіх ресурсів людини.

3. Період повернення. Саме повернення до “нормальних" умов для військовослужбовця, який адаптувався до “ненормальних", є стресовим, а в деяких випадках - і травматичним. На відміну від інших стресових ситуацій спочатку той стрес, що переживають учасники бойових дій при поверненні до звичайного життя, може не усвідомлюватися, маскуватись почуттям радості, ейфорією, які потім змінюються астенією, пригніченістю, а також почуттям розчарування, роздратування та гніву $[8,26]$.

У деяких випадках зміна ситуації на більш-менш “нормальну” може стати травматичною. Переживання повернення можуть стати схожими на переживання травматичної події. Це нерідко відбувалося в таких випадках, коли ті, хто повернувся зі служби в армії, комбатанти, виявляли, що навколишні байдуже, навіть негативно ставляться до їх участі у військових діях. Саме тому фаза “повернення" неоднорідна і може призвести як до нової успішної адаптації людини до нових умов, так і до розвитку дезадаптації та всіх патологічних наслідків перенесеної травми. При розвитку психічної травми в наслідок тривалого перебування військовослужбовця в бойових умовах найбільш доцільною буде робота в межах довгострокової психотерапії та психореабілітації.

На розвиток та переживання психічної травми впливають різноманітні соціально-психологічні детермінанти, які, на думку Л. Трубіциної, можливо об'єднати у три основні блоки $[10,108]$ :

соціально-психологічні детермінанти, що передували екстремальній ситуації та які можуть вплинути на процес психотравматизації особистості;

соціально-психологічні детермінанти, що діють безпосередньо в осередку екстремальної ситуації;

соціально-психологічні детермінанти, що впливають на розвиток та переживання 


\section{Питання психології}

особистістю психічної травми у постстресовий період.

Розглянемо основні здобутки сучасних дослідників в межах виділених трьох основних блоків більш детально.

Індивідуальні психофізіологічні особливості, що значно впливають на переживання травмуючої ситуації. Деякі дослідження показують роль міжкульової асиметрії в більш успішному переживанні тривалих екстремальних ситуацій. $\mathrm{У}$ незвичайних, екстремальних умовах середовища увагу отримують особи 3 найменшою спеціалізацією півкуль мозку (амбідекстри та лівші).

Велике значення має фізична форма людини. У спортсменів, особливо висококваліфікованих, межі гомеостазу у стані спокою, у процесі тренувань і змагань встановлюються на іншому, значно більш широкому рівні, ніж в осіб, які не займаються систематично спортом.

До негативних факторів, що підвищують ризик розвитку посттравматичного стресового розладу (далі- ПТСР), відносять: акцентуації характеру, невротичність, схильність до наркоманії i асоціальної поведінки, обтяженість психічною патологією, психічні захворювання, що передували травмі (особливо порушення поведінки), наявність психічних захворювань у членів родини (тривожних розладів, депресії, алкоголізму тощо).

До групи факторів ризику до бойового періоду життя учасника бойових дій відноситься сімейний стан. У чоловіків на вразливість до ПТСР впливають також ïx вік, в якому вони пішли на війну (військовослужбовці молодшого віку більш уразливі до психотравмуючих факторів бойової обстановки).

Особливу роль у реакції на травмуючи подію відіграє світогляд та ціннісні орієнтації особистості. Також виявлено, що стійкі ідеологічні погляди сприяють адаптації до травми. Хоча природна реакція на стресову подію $\epsilon$ багатодетермінованою, первинними детермінантами індивідуальних відмінностей $\epsilon$ природа i інтенсивність зовнішньої події. Тривалість та інтенсивність впливу стресора корелюють iз тяжкістю ПТСР. Для наслідків події більш важливим $\epsilon$ не іiі характеристики, а особливості ставлення до них людини і їі поведінки під час бойових дій.

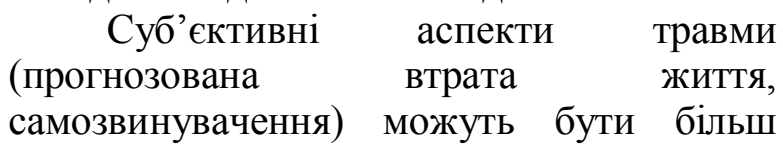
$\begin{array}{lr}\text { самозвинувачення) } & \text { можуть бути більш } \\ \text { важливими } & \text { детермінантами }\end{array}$ психологічного дистресу, ніж об’єктивні фактори (фізичні ушкодження, насильство, використання зброї) $[10,58]$.

У тих випадках, коли людина, здавалося б, нічого не може вдіяти, вона може змінити своє ставлення до ситуації, надати ій новий сенс. “... У нацистських концтаборах в'язні, які вважали, що сенс їхнього життя - показати можливість виживання в таких нелюдських умовах, i твердо вірили у своє визволення, легше переносили випробування, що випадало на їхню долю. Вони залишилися живі, здоров'я їх постраждало менше, ніж у в'язнів , які вважали безглуздою i безнадійною своє життя у таборах. Цей прийом “позитивного тлумачення" неприємного i морально важкого переживання все частіше використовувався в лікарняній практиці " $[3,32]$.

Не менш ефективною, але часом необхідною в екстремальній ситуації є така стратегія поведінки людини, як заперечення. Заперечення може допомогти уникнути миттєвої руйнівної дії події, дозволяючи людині пережити іï поступово. Але рано чи пізно людині все-таки доведеться прийняти реальність $[5,11]$.

Існують також й інші способи поведінки в екстремальних умовах, які б забезпечили виживання в них, серед них догляд. Коли неможливо вийти із ситуації фізично, людина може робити це подумки. “Якщо ув'язнений виявляв, що він не може більше виносити реальність табірного життя, він знаходив у своєму духовному житті можливість виходу, яку важко переоцінити, - можливість відходу у духовну сферу, яку не в змозі зруйнувати... " $[11,153]$. Один із ефективних прийомів більш успішного подолання травмуючої ситуації - дисоціація (погляд на події ззовні, зі сторони). Подібний прийом часто виявляється характерним для людей, які найбільш психологічно благополучно пережили надзвичайну ситуацію. Про використання такого прийому в концтаборі говорив i В. Франкл: "Я сам весь час намагався вдаватися до засобів, що 


\section{Питання психології}

дозволяли мені дистанціонюватися від усього страждання, яке нас оточувало. Я намагався об'єктувати його" $[11,154]$.

Таким чином, факторами, що сприяють більш психологічно благополучному переживанню травмуючої ситуації, $є$ велика активність людини (фізична і психологічна), прийняття на себе більшого контролю, використання прийомів догляду, дисоціації, зміщення акцентів, уявного вирішення проблем.

Говорячи про наслідки перебування військовослужбовців в умовах проведення бойових дій на території Донецької та Луганської областей, необхідно розмежувати:

процес нормального переживання психічної травми (тобто процес переживання травми, який веде до відновлення після неї);

процес патологічний (такий, що “застрягає", що веде до розвитку різноманітних патологічних станів, хронічних порушень та особистісних змін).

Оскільки мета психологічної допомоги i реабілітації полягає у відновленні порушених психічних функцій (відображення впливів навколишнього світу, усвідомлення людиною свого місця в навколишньому світі, регуляція поведінки та діяльності), психічних утворень (певних навичок та умінь) та деструктивних особистісних змін внаслідок отримання учасниками бойових дій психічних травм, в зазначеному контексті нас цікавить саме розгляд особливостей віддалених наслідків травматизації.

Сучасні дослідження дозволять говорити про існування різноманітних віддалених наслідків психічних травм, які можна подати у вигляді наступних блоків:

1. Нервово-психічні захворювання, психологічні порушення та зміни (вивчаються в межах концепції посттравматичних стресових порушень).

2. Проблеми соціальної дезадаптації, реадаптації та необхідності адаптації до нової ситуації (вивчаються в межах підходу адаптаційних можливостей організму людини).

3. Соціальні проблеми, які пов'язані 3 наслідками травми.

До першого блоку наслідків травматизації, що може виникнути у учасників бойових дій, входять різноманітні нервово-психічні захворювання, психічні порушення та зміни, що вивчаються в межах концепції ПТСР. Згідно з МКХ-10 ПТСР (F43.1) є розладом, що виникає як відстрочена i/aбо затяжна реакція на екстремальну (травматичну) подію або ситуацію (короткочасну або затяжну) загрозливого або катастрофічного характеру, що може викликати загальний дистрес майже в будь-якої людини.

До клінічних діагностичних критеріїв відносяться наступні: перебування людини в осередку екстремальної травматичної події, пов'язаної із загибеллю або серйозними пораненнями інших людей; травматична подія нав'язливо повторюється у образах, думках і почуттях, що викликають тяжкі емоційні переживання; спостерігається постійне уникання стимулів, пов'язаних із травмою; наявні постійні симптоми гіперактивації, що не спостерігається до травми. Перелічені симптоми спостерігаються більше шести місяців після травмування i викликають порушення адаптації в соціальній, професійній або інших важливих сферах життєдіяльності людини. Поряд із ПТСР, у учасників бойових дій досить часто мають місце порушення, що відносяться до інших психічних розладів. Особливо часто спостерігається сполучення ПТСР із депресіями та різними формами хімічної залежності, можуть відзначатися поєднання ПТСР is панічними, обсесивнокомпульсивними, тривожно-фобічними розладами, суїцидальною поведінкою тощо.

Рівень

поширеності посттравматичних стресових розладів у військових ветеранів в жодній країні світу не сягає менше $15 \%$. У більшості досліджень, проведених щодо цієї проблематики, з'ясовано, що поширеність ПТСР серед військових ветеранів становить 15-25\% (Бром і Клебер, 1989), або 15-35\% (Кін, 1985), при цьому вона може бути більшою. Найбільше випадків ПТСР фіксують серед колишніх військовополонених - до 85\% (Урсано і Рундел, 1995). Трьома хорватськими дослідженнями встановлено, що ПТСР можуть мати приблизно 14-41,7\% хорватських військових і військових ветеранів (Гусович і Камар, 1994; 


\section{Питання психології}

Кушевич, 1998; Комар і Вуушич, 1999) [4, 34].

До другого боку наслідків травматизації відносяться різноманітні розлади учасників ООС (АТО). Згідно 3 MКX-10 розлади адаптації (F43.2) - це стани об'єктивного дистресу й емоційного розладу, які, зазвичай, перешкоджають соціальному функціонуванню i продуктивності i виникають в період адаптації до значної зміни в житті або стресовій події. У $\mathrm{MKX-10} \mathrm{існує}$ діагностична рубрика "Хронічна зміна особистості після переживання катастрофи" (F62.0), що може розвиватися після ПТСР і $є$ вже практично незворотним хворобливим станом. У цих випадках зміни особистості мають стабільний характер i проявляються ригідними і дезадаптивними ознаками, що призводять до стійких порушень у міжперсональному, соціальному i професійному функціонуванні. Проявами таких порушень $\epsilon$ недовірливе або навіть вороже ставлення до оточення, соціальна відгородженість, відчуття спустошення і безнадії, хронічне відчуття тривоги або постійної зовнішньої загрози, прояви “відлюдненості”, депресії. Такі хронічні зміни особистості досить часто проявляються асоціальною поведінкою, девіантні наслідки якої у більшості випадків мають злочинні ознаки.

Так, після війни у В'єтнамі Сполучені Штати Америки втратили людей значно більше, ніж під час бойових дій через алкоголізм, наркоманію, самогубства, криміналізацію колишніх військових. У $25 \%$ учасників бойових дій, які навіть не мали каліцтва, згодом загострилися різні психічні та психологічні порушення, а серед поранених і покалічених таких було $42 \%$, до 60 тис. ветеранів у різний час наклали на себе руки, а від 35 до 45 тис. донині ведуть донині ведуть усамітнений спосіб життя [4,23].

Варто зазначити, що психологічні зміни, які виникають у військовослужбовців після участі у бойових діях, також зачіпають i підструктуру їхньої спрямованості (світогляду, переконання тощо) i нам представляється доцільним більш детально розглянути питання, пов'язані 3 сенсом життя учасників бойових дій.
Окремі автори висловлюють думку, що у ветеранів, які отримали поранення, не можна очікувати особистісних змін позитивного регістру. Робіт, що підтверджують або спростовують цей факт, практично немає, проте, є припущення, що при згасанні функції тіла часто спостерігається духовний сплеск. Важка хвороба або поранення змушують переглянути своє ставлення до близьких людей, до планів на майбутнє, думки звертаються всередину, приходить бажання усвідомити сенс життя.

На блоці соціальних проблем, які пов'язані 3 наслідками травматизації особистості хотілося б зупинитися докладніше. Більшість закордонних вчених наголошують на тому, що постраждалі від різноманітних екстремальних ситуацій чинять помітний вплив на своє найближче оточення, i, перш за все, на членів власної сім'ї. Наслідки значних екстремальних ситуацій впливають і на мікросоціальні процеси, а іноді - i на все суспільство в цілому, а через нього - на індивідів, які його утворюють. Родини ветеранів $\mathrm{y}$ багатьох випадках співпереживають травму. Дослідження сімей, які пережили Голокост, та ветеранів В'єтнаму показали наявність у членів родин високого рівня депресії, поганого контролю над імпульсивною поведінкою, наявність почуття провини, зловживання різними наркотичними речовинами та інші ускладнення [4, 67]. Наявність ПТСР та іншої психопатології, а також труднощі соціальної адаптації, зазвичай, порушують, функціонування сімей, перетворюючи їх іноді в дисфункціональні. Це, в свою чергу, може провокувати й нові проблеми у майбутньому. Масові масштабні події, що травмують, можуть у якості віддалених наслідків при несприятливому розвитку та недостатній допомозі призвести до того, що К. Еріксон називає "колективною травмою", "суспільною травмою”, а також до появи “травмованих суспільств” [6, 54].

\section{Висновки та перспективи} подальших досліджень

1. Аналіз наукової літератури та практики застосування військ (сил) під час проведення операції Об'єднаних сил дозволяе виокремити наступні характеристики сучасної бойової діяльності військовослужбовців: велика 


\section{Питання психології}

соціально-психологічна значимість, специфічні цілі (знищення супротивника), екстремальні умови (небезпека, раптовість, новизна), високе напруження моральних та фізичних сил. Серед значущих екстремальних стрес-факторів особливої ваги набувають: термінальні фактори, візуальна деструкція, соціальні фактори, інформаційні фактори, біологічні фактори, фактор вимушеної деструктивної діяльності, фактор соціальної незахищеності, відсутність чітко визначених суспільно-політичних позицій по відношенню до збройного конфлікту.

2. Проведене дослідження впливу стрес-факторів бойової обстановки на психічну сферу особистості дозволяє виокремити негативні та позитивні особисті трансформації. До позитивних трансформацій, на нашу думку, можна віднести: формування більш серйозного ставлення до життя, глибокого розуміння життєвих цінностей, посилення цілеспрямованості, раціональності, реалістичності, кмітливості та критичності мислення, наявність позитивних змін в самосприйнятті та самооцінці, позитивній зміни загальної філософії життя, що в цілому може вивести особистість на новий рівень розвитку. Разом 3 тим, участь військовослужбовців у бойових діях являється предиктором розвитку гострих реакцій на стрес, ПТСР, різноманітних розладів адаптації, стійких змін особистості, виникнення родинних проблем, соціальної ізоляції, ворожості до оточення, зловживання наркотичними речовинами та алкоголем тощо.

Перспективи

подальших досліджень вбачаємо у обгрунтуванні рекомендацій щодо удосконалення системи надання психологічної допомоги та реабілітації в Збройних Силах України.

\section{Список використаних джерел}

1. Агаєв Н.А. Психологічна реабілітація військовослужбовців. Київ : МОУ 2005. с.74.

2. Беккио Ж. Гипноз XXI века. Москва : Класс, 2003. с.272.

3. Караяни А. Екстренная психологическая помощь военнослужащим в бою. Москва : Центр, 1995. с.32.

4. Комар 3. Психологічна стійкість воїна: підручник для військових психологів. Київ, 2017. 184 с.

5. Лебедев В. Личность в экстремальных условиях. Москва : Политиздат, 1989. с.304.

6. Малкина-Пых И. Экстремальные ситуации. Москва : Эксмо, 2005. с.958.

7. Медынская Ю. Основные теоретические подходы к проблеме посттравматического стресса. URL: http://www.psychology.ru/lomonosov/tesises/fy.htm (дата звернення: 01.11.2019).

8. Побідаш А.Ю. Психологічні особливості життєвої стійкості моряків жертв піратського полону. Харків : КП “Міська друкарня”, 2012. с.196.

9. Стасюк В. В. Психологія локальних війн та збройних конфліктів : підручник для слухачів та студентів вищих навчальних закладів. Київ : НУОУ ім. І. Черняховського, 2016. 412 с.

10. Трубицина Л.В. Переживание травмирующего события как проблема психологии личности. Москва : Прогресс, 2005. с.201.

11. Франкл В. Человек в поисках смысла. Москва : Прогресс, 1990. с.368.

\section{References}

1. Ahaiev, N. A. (2005). Psykholohichna reabilitatsiia viiskovosluzhbovtsiv [Psychological rehabilitation of military personnel]. Kyiv : MOU. (in Ukrainian).

2. Bekkio, Zh. (2003). Gipnoz XXI veka [Hypnosis of the 21st Century]. Moskva : Klass. (in Russian).

3. Karajani, A. (1995). Ekstrennaja psihologicheskaja pomoshh' voennosluzhashhim v boju [Emergency psychological assistance to military personnel in battle]. Moskva : Centr. (in Russian).

4. Komar, Z. (2017). Psykholohichna stiikist voina: pidruchnyk dlia viiskovykh psykholohiv [Psychological stability of serviceman : a textbook for military psychologists]. Kyiv. (in Ukrainian).

5. Lebedev, V. (1989). Lichnost' v jekstremal'nyh uslovijah [Extreme personality]. Moskva. (in Russian).

6. Malkina-Pyh, I. (2005). Jekstremal'nye situacii [Extreme situations]. Moskva. (in Russian).

7. Medynskaja, Ju. Osnovnye teoreticheskie podhody k probleme posttravmaticheskogo stressa [The main theoretical approaches to the problem of post-traumatic stress]. Retrieved from http://www.psychology.ru/lomonosov/tesises/fy.htm. (in Russian).

8. Pobidash, A.U. (2012). Psykholohichni osoblyvosti zhyttievoi stiikosti moriakiv zhertv piratskoho polonu [Psychological features of life sustainability of seafaring victims of pirate captivity]. Kharkiv : KP "Miska drukarnia". (in Ukrainian). 


\title{
Питання психології
}

9. Stasiuk, V. V. (2016). Psykholohiia lokalnykh viin ta zbroinykh konfliktiv : pidruchnyk dlia slukhachiv ta studentiv vyshchykh navchalnykh zakladiv [Psychology of local wars and armed conflicts]. Kyiv : NUOU im. I. Cherniakhovskoho. (in Ukrainian).

10. Trubicina, L.V. (2005). Perezhivanie travmirujushhego sobytija kak problema psihologii lichnosti [The experience of a traumatic event as a problem of personality psychology]. Moskva : Progress. (in Russian).

11. Frankl, V. (1990). Chelovek v poiskah smysla [Man in search of meaning]. Moskva : Progress. (in Russian).

\author{
Резюме \\ Павлушенко С. слушатель групи 1201, Інститут \\ государственного военного управления Национального \\ университета обороны Украины имени Івана Черняховского \\ ПСИХОЛОГИЧЕСКИЕ ПОСЛЕДСТВИЯ УЧАСТИЯ ЛИЧНОСТИ В БОЕВЫХ \\ ДЕЙСТВИЯХ
}

В статье росмотрено стрес-факторы боевой обстановки; проанализировано этапь, механизмы і сочиально-психологические детерминанты, которые определяют процес переживания военнослужащим психологической травмы.

Ключові слова: психологическая помощь; психологическая реабилитация; посттравматические стресовые ростройства.

\section{Summary \\ Pavlushenko S. listener Institute \\ PSYCHOLOGICAL CONSEQUENCES OF PARTICIPATION OF THE PERSONAITTY IN BATTLE ACTIONS}

Prolonged military conflict in the territory of Donetsk and Luhansk oblasts of the state, its further uncertainty, potential threat to life and health, prolonged stay in the area of hostilities, unsettled life, heavy physical and psychological stress on personnel and other factors of combat situation long-term disorders of the psyche, reduce the combat capability of military units (units). Along with gaining combat experience, participants in the war in the East of our country are physically and mentally traumatized, requiring further professional help and rehabilitation. The creation of an effective system of psychological assistance and rehabilitation in the present conditions is possible only with the understanding of the psychological consequences of the participation of personnel in hostilities in the Donetsk and Luhansk regions.

Purpose. Analysis of the psychological consequences of military involvement.

Methods.The theoretical methods of research were used to solve the problems set in the work: analysis of scientific sources on the problem of research, synthesis, comparison, generalization.

Originality. The article deals with the stress factors of the combat situation; stages, mechanisms and socio-psychological determinants that determine the process of experiencing mental trauma by military personnel are analyzed

Conclusion:

1. Analysis of the scientific literature and practice of the use of troops (forces) during the operation of the Joint Force allows to distinguish the following characteristics of modern military activity of military personnel: great socio-psychological significance, specific goals (destruction of the enemy), extreme conditions (danger, suddenness, novelty), high tension of moral and physical forces. Among the significant extreme stressors of particular importance are: terminal factors, visual destruction, social factors, information factors, biological factors, the factor of forced destructive activity, the factor of social insecurity, the absence of clearly defined socio-political positions in relation to the conflict.

2. The study of the influence of stressors of the combat situation on the mental sphere of the individual allows to distinguish negative and positive personal transformations. Positive transformations, in our opinion, can be attributed to: formation of a more serious attitude to life, deep understanding of vital values, strengthening of purposefulness, rationality, realism, ingenuity and critical thinking, presence of positive changes in self-perception and self-esteem, positive as a whole can take a person to a new level of development. However, the participation of military personnel in combat is a predictor of the development of acute reactions to stress, PTSD, various disorders of adaptation, persistent personality changes, the emergence of family problems, social isolation, hostility to the environment, abuse of drugs and alcohol, etc.

3. We see prospects for further research in substantiating the recommendations for improving the system of psychological assistance and rehabilitation in the Armed Forces of Ukraine.

Key words: psychological assistance; psychological rehabilitation; post-traumatic stress disorders. 